\title{
Gambaran kadar asam urat pada penderita tuberkulosis paru yang menerima terapi obat anti tuberkulosis di RSUP Prof. Dr. R. D. Kandou Manado periode Juli 2014 - Juni 2015
}

\author{
${ }^{1}$ Irwanto Kondo \\ ${ }^{2}$ M. C. P Wongkar \\ ${ }^{2}$ Jeffrey Ongkowijaya
}

\author{
${ }^{1}$ Kandidat Skripsi Fakultas Kedokteran Universitas Sam Ratulangi Manado \\ ${ }^{2}$ Bagian Ilmu Penyakit Dalam Fakultas Kedokteran Universitas Sam Ratulangi Manado \\ Email: irwanto097@gmail.com
}

\begin{abstract}
Pulmonary tuberculosis is a chronic infectious disease caused by Mycobacterium tuberculosis. There are 6 kinds of essential drugs which have been used: isoniazid, amino salicylic acid, streptomycin, ethambutol, rifampicin, and pyrazinamide. As reported, pyrazinamide and ethambutol can cause increased levels of uric acid. This study aimed to obtain the uric acid profile in tuberculosis patients treated with antituberculosis drugs in Prof. Dr. R. D. Kandou Hospital Manado. This was a retrospective descriptive study using data of the Medical Record Department of Prof. Dr. R. D. Kandou Hospital Manado. Of 25 tuberculosis patients treated with antituberculosis drugs, the uric acid levels were as follows: high in 15 patients (60\%), normal in 9 patients (36\%), and low in 1 patient (4\%). The highest proportion of tuberculosis patients who had hyperuricemia after treated with antituberculosis drugs were male (73.33\%) and age 46-65 years (46.67\%). The increased uric acid level mainly occurred in the intensive phase of treatment (0-2 months), and in patients taking the combination of pyrazinamide and ethambutol. The most common comorbid disease was anemia (53.33\%). Conclusion: Hyperuricemia was found in $60 \%$ of TB patients receiving antituberculosis drugs with a male : female ratio 2.75:1, mainly occurred in the intensive phase of treatment (0-2 months) and in patients who used a combination of pyrazinamide and ethambutol.
\end{abstract}

Keywords: pulmonary tuberculosis, anti-tuberculosis drugs, uric acid

\begin{abstract}
Abstrak: Tuberkulosis (TB) paru adalah suatu penyakit infeksi kronik yang disebabkan Mycobacterium tuberculosis. Terdapat 6 macam obat esensial yang telah dipakai, yaitu: isoniazid $(\mathrm{H})$, para amino salisilik asid, streptomisin, etambutol, rifampisin, dan pirazinamid. Pirazinamid dan etambutol dilaporkan dapat menyebabkan peningkatan kadar asam urat. Penelitian ini bertujuan untuk mendapatkan gambaran kadar asam urat pada pasien TB paru yang menerima obat antituberkulosis (OAT) di RSUP Prof. Dr. R. D. Kandou Manado. Jenis penelitian ini deskriptif retrospektif dengan mengambil data sekunder di Instalasi Rekam Medik RSUP Prof. Dr. R. D. Kandou Manado. Hasil pemeriksaan laboratorium dari 25 pasien TB yang menjalani terapi OAT memperlihatkan 15 pasien (60\%) dengan kadar asam urat tinggi, 9 pasien (36\%) normal, dan 1 pasien (4\%) kadar asam urat rendah. Proporsi tertinggi pasien TB yang mengalami hiperurisemia setelah menerima OAT ialah laki-laki (73,33\%), rentang umur 46-65 tahun (46,67\%). Peningkatan terutama terjadi pada fase intensif pengobatan ( $0-2$ bulan), dan pada pasien yang mengonsumsi kombinasi pirazinamid dan etambutol. Penyakit komorbid terbanyak ialah anemia (53,33\%). Simpulan: Hiperurisemia ditemukan pada $60 \%$ pasien TB yang menjalani terapi OAT, jenis kelamin laki-laki lebih banyak dari perempuan (2,75:1), peningkatan terutama terjadi pada pengobatan fase intensif ( $0-2$ bulan), dan pada pasien yang menggunakan kombinasi pirazinamid dan etambutol.
\end{abstract}

Kata kunci: tuberkulosis paru, obat anti tuberkulosis, asam urat 
Tuberkulosis paru (TB) adalah suatu penyakit infeksi kronik yang sudah sangat lama dikenal pada manusia yang disebabkan Mikobakterium tuberkulosis.

Sejak tahun 1993, WHO menyatakan bahwa TB merupakan kedaruratan global bagi kemanusiaan. TB dianggap sebagai salah masalah kesehatan dunia yang penting kerena lebih kurang 1/3 penduduk dunia terinfeksi oleh Mikobakterium tuberkulosis. ${ }^{1}$ Pada Tahun 2013 diperkirakan 9 juta orang menderita TB dan 1.5 juta diantaranya meninggal dunia. ${ }^{2}$ Indonesia merupakan negeri dengan prevalensi TB ke-5 tertinggi di dunia setelah India (2,0-2,3 juta), China (0,9-1,1 juta), Nigeria (340.000-880.000), Pakistan (370.000-650.000), dan Indonesia (410.000-520.000). ${ }^{2}$ Berdasarkan survei kesehatan rumah tangga 1985 dan survei kesehatan nasional 2001, TB menempati ranking nomor 3 sebagai penyebab kematian tertinggi di Indonesia. ${ }^{1}$

Faktor risiko yang menyebabkan tingginya prevalensi TB di Indonesia, antara lain: kurangnya gizi, kemiskinan, dan sanitasi yang buruk. ${ }^{3}$ TB ditularkan lewat udara, bakteri TB tersebar ketika pasien TB batuk, bersin, berbicara. ${ }^{4}$

Program nasional pemberantasan TB di Indonesia sudah dilaksanakan sejak tahun 1950-an. Terdapat 6 jenis obat esensial yang telah dipakai, yaitu: isoniazid $(\mathrm{H})$, para amino salisilik asid (PAS), streptomisin (S), etambutol (E), rifampisin (R), dan pirazinamid (P). Sejak tahun 1994 program pengobatan TB di Indonesia sudah mengacu pada program Directly Observed Treatment Short Course Strategy (DOTS) yang didasarkan pada rekomendasi WHO. ${ }^{3}$ Pirazinamid dan etambutol dilaporkan dapat menyebabkan hiperurisemia, ${ }^{3}$ yaitu keadaan konsentrasi asam urat serum lebih dari $7 \mathrm{mg} / \mathrm{dL}$ pada laki-laki dan lebih dari $6 \mathrm{mg} / \mathrm{dL}$ pada perempuan. ${ }^{5}$ Salah satu keluhan tersering pada pasien yang menerima terapi pirazinamid ialah artralgia yang berhubungan dengan peningkatan kadar asam urat serum. ${ }^{6}$ Pirazinamid diketahui memfasilitasi pertukaran ion di tubuli ginjal yang menyebabkan reabsorpsi berlebihan asam urat sehingga menimbulkan hiperurisemia. Sejumlah penelitian telah membuktikan bahwa terdapat hubungan antara peningkatan kadar asam urat dengan terapi OAT pada penderita TB. Pada penelitian yang dilakukan di RSUP Prof. Dr. R. D. Kandou Manado tahun 2013, dilaporkan terjadi peningkatan kadar asam urat serum pada 41 (100\%) sampel dan hiperurisemia 39 (95\%) sampel yang menerima OAT. $^{7}$ Pada penelitian di Kasturba Chest Hospital, India didapatkan hiperurisemia pada 73 pasien yang menerima terapi OAT $(69,9 \%) .{ }^{8}$ Penelitian ini bertujuan untuk mengetahui gambaran kadar asam urat pada penderita TB yang menjalani terapi OAT di RSUP Prof. Dr. R. D. Kandou Manado.

\section{METODE PENELITIAN}

Jenis penelitian ini ialah deskriptif retrospektif menggunakan data sekunder di Bagian Rekam Medik RSUP Prof. Dr. R.D. Kandou Manado. Penelitian dilakukan pada bulan Oktober - Desember 2015. Sampel penelitian ialah semua pasien tuberkulosis yang menerima terapi OAT di RSUP Prof. Dr. R. D. Kandou Manado periode Juli 2014 - Juni 2015.

\section{HASIL PENELITIAN}

Berdasarkan penelitian yang dilakukan terhadap pasien tuberkulosis paru di RSUP Prof. Dr. R. D. Kandou periode Juli 2014 Juni 2015, diperoleh data yang disajikan dalam tabel sebagai berikut:

Tabel 1. Distribusi berdasarkan kadar asam Urat

\begin{tabular}{ccc}
\hline Kadar asam urat & Jumlah pasien & $(\%)$ \\
\hline Tinggi & 15 & 60 \\
Normal & 9 & 36 \\
Rendah & 1 & 4 \\
Total & 25 & 100 \\
\hline
\end{tabular}

Tabel 2. Distribusi berdasarkan jenis kelamin

\begin{tabular}{lcc}
\hline Jenis kelamin & Jumlah pasien & $(\%)$ \\
\hline Laki-laki & 11 & 73,33 \\
Perempuan & 4 & 26,67 \\
Total & 15 & 100 \\
\hline
\end{tabular}


Tabel 3. Distribusi berdasarkan usia

\begin{tabular}{ccc}
\hline $\begin{array}{c}\text { Umur pasien } \\
\text { (tahun) }\end{array}$ & Jumlah & (\%) \\
\hline $12-25$ & 1 & 6,67 \\
$26-45$ & 4 & 26,67 \\
$46-65$ & 7 & 46,67 \\
$>65$ & 3 & 20 \\
Total & 15 & 100 \\
\hline
\end{tabular}

Tabel 4. Distribusi berdasarkan lama konsumsi OAT

\begin{tabular}{ccc}
\hline $\begin{array}{c}\text { Lama konsumsi OAT } \\
\text { (bulan) }\end{array}$ & Jumlah & (\%) \\
\hline $1 \leq$ & 9 & 60 \\
$2-3$ & 3 & 20 \\
$4-5$ & 2 & 13,33 \\
$>5$ & 1 & 6,67 \\
Total & 15 & 100 \\
\hline
\end{tabular}

Tabel 5. Distribusi berdasarkan jenis OAT yang dikonsumsi

\begin{tabular}{lcc}
\hline Jenis OAT & Jumlah & $(\%)$ \\
\hline Kombinasi pirazinamid & 10 & 66,67 \\
dan etambutol & & \\
Pirazinamid & 2 & 13,33 \\
Ethambutol & 3 & 20 \\
Total & 15 & 100 \\
\hline
\end{tabular}

Tabel 6. Distribusi berdasarkan komorbid

\begin{tabular}{lcc}
\hline Komorbid & Jumlah & $(\%)$ \\
\hline Sindrom dispepsia & 6 & 40 \\
Hipertensi & 2 & 13,33 \\
Diabetes melitus & 2 & 13,33 \\
Anemia & 8 & 53,33 \\
Hepatitis & 1 & 6,67 \\
Pneumonia & 3 & 20 \\
\hline
\end{tabular}

\section{BAHASAN}

Berdasarkan data yang diperoleh dari rekam medik, pasien yang diperiksa kadar asam urat serumnya setelah menerima terapi OAT di bagian Ilmu Penyakit Dalam Prof. Dr. R. D. Kandou Manado pada periode Juli 2014 - Juni 2015 sebanyak 25 orang, dan 15 (60\%) diantaranya mengalami peningkatan kadar asam urat serum.

Berdasarkan jenis kelamin, pasien dengan peningkatan kadar asam urat setelah menerima terapi OAT yang berjenis kelamin laki-laki lebih banyak dari perempuan, dengan rasio perbandingan sebesar 2,75 : 1 . Perbedaan ini mungkin disebabkan oleh angka kejadian TB paru yang lebih tinggi pada laki-laki diduga akibat perbedaan pajanan dan risiko infeksi. Hal ini karena laki-laki sebagian besar mempunyai kebiasaan merokok, minum alkohol, dan menggunakan obat obatan terlarang; selain itu, faktor

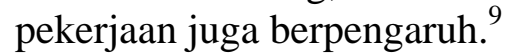

Berdasarkan umur angka kejadian terbanyak terjadi pada kelompok umur 4665 tahun sebanyak 7 pasien (46,67\%) dan terbanyak kedua pada kelompok umur 2645 tahun sebanyak 4 pasien (26,67\%). TB sebagian besar memengaruhi orang dewasa di tahun paling produktif. Hal ini terjadi karena pada kelompok usia produktif setiap orang akan cenderung beraktivitas tinggi, sehingga kemungkinan untuk terpapar kuman Mikobakterium tuberkulosis lebih besar; namun, semua kelompok umur tetap berisiko. $^{10}$

Berdasarkan lama penggunaan OAT, didapatkan bahwa jumlah pasien yang mengalami pengingkatan OAT setelah mengonsumsi OAT selama 1 bulan atau kurang sebanyak 9 pasien (60\%), 2-3 bulan sebanyak 3 pasien (20\%), 4-5 bulan sebanyak 2 pasien (13,33\%), dan $>5$ bulan sebanyak 1 pasien (6,67\%). Hal ini sesuai dengan penelitian sebelumnya yang menyebutkan bahwa peningkatan bermakna kadar asam urat serum pada pengobatan dengan OAT terutama terlihat pada minggu ke-4 dan relatif menetap pada minggu ke-8. Terjadi penurunan bermakna kadar asam urat serum setelah masuk minggu ke-12 (fase lanjutan), walaupun belum kembali ke kadar sebelum pengobatan. $^{7}$

Berdasarkan jenis OAT yang digunakan, peningkatan kadar asam urat terjadi pada pasien yang menggunakan kombinasi pirazinamid dan etambutol yaitu sebanyak 10 pasien $(66,67 \%)$, pirazimanid sebanyak 2 pasien (13,33\%), dan etambutol sebanyak 3 pasien (20\%). Hal ini sesuai dengan penelitian sebelumnya oleh Khanna et al. dimana kejadian hiperurisemia lebih tinggi pada kombinasi pirazinamid dan 
etambutol dibanding dengan pemberian pirazinamid atau etambutol saja. ${ }^{8}$ Pirazinamid dan etambutol memfasilitasi pertukaran ion di tubuli ginjal yang menyebabkan reabsorpsi berlebihan asam urat sehingga menimbulkan.hiperurisemia dan jika kedua obat digunakan bersamaan efek yang ditimbulkan lebih besar. ${ }^{7}$

Berdasarkan penyakit komorbid, terbanyak ialah anemia 8 pasien (53,33\%), diikuti sindrom dispepsia sebanyak 6 pasien (40\%), hipertensi 2 pasien (13,33\%), diabetes melitus 2 pasien (13,33\%), hepatitis 1 pasien (6,67\%), dan pneumonia sebanyak 3 pasien (20\%). Anemia merupakan komplikasi umum dari TB paru dan prevalensi dilaporkan sekitar 16-76 \% dalam studi yang berbeda. ${ }^{10}$ Anemia merupakan kelainan hematologi umum pada pasien dengan TB dan pemantauan perlu dilakukan. Anemia terkait TB biasanya ringan dan sembuh dengan pengobatan anti $\mathrm{TB}^{11}$ Selain itu, infeksi kronis termasuk TB dapat menyebabkan anemia. ${ }^{12}$ Anemia pada tuberkulosis dapat dikarenakan terjadinya gangguan pada proses eritropoesis oleh mediator inflamasi, pemendekan masa hidup eritrosit, gangguan metabolisme besi, adanya malabsorbsi dan ketidakcukupan zat gizi dikarenakan rendahnya nafsu makan. Baik anemia penyakit kronik maupun anemia defisiensi besi dapat terjadi pada penderita tuberkulosis. ${ }^{13}$

\section{SIMPULAN}

Hiperurisemia ditemukan pada 60\% pasien TB yang menjalani terapi OAT, dengan jenis kelamin laki-laki lebih banyak dari perempuan (2,75:1), golongan umur 46-65 tahun, pada pengobatan fase intensif (0-2 bulan), dan pada pasien yang menggunakan kombinasi pirazinamid dan etambutol. Penyakit komorbid terbanyak ialah anemia.

\section{DAFTAR PUSTAKA}

1. Amin Z, Bahar A. Tuberculosis paru. In: Setiawati S, Alwi I, Sudoyo AW, Simadibrata KM, Setiyohadi B, Syam AF, editors. Buku Ajar Ilmu Penyakit
Dalam (4th ed). Jakarta: InternaPublishing, 2014; p. 863-72.

2. WHO. Global tuberculosis report, 2014.

3. Amin Z, Bahar A. Pengobatan Tuberculosis Mutakhir. In: Setiawati S, Alwi I, Sudoyo AW, Simadibrata KM, Setiyohadi B, Syam AF, editors. Buku Ajar Ilmu Penyakit Dalam (4th ed). Jakarta: InternaPublishing, 2014; p. 873-81.

4. Ernst JD, Trevejo-Nuñez1 G, Banaiee N. Genomics and evolution, pathogenesis and diagnosis of tuberculosis. J Clin Invest. 2007;117 (7):1738-45.

5. Ferre MG, Bullo M, Babio N, Gonzalez MAM., Estruch R, Covas MI, et al. Mediterranean diet and risk of hyperuricemia in elderly. J Gerontol Med Sci. 2013;68;1-8.

6. Qureshi W, Hassan G, Kadri SM, Khan GQ, Samuel B, Arshad Ali. Hyperuricemia and arthralgias during pyrazinamide therapy in patients with pulmonary tuberculosis. Labmedicine. 2007;38;495-7.

7. Diana, Karema-Kaparang AMC, Matheos JC, Dosis tetap terhadap kadar asam urat pada pasien tuberkulosis paru. J Indon Med Assoc. 2013.63;91-4.

8. Khanna BK, Kumar J. Hyperuricemic effect of ethambutol and pyrazinamide administered concomitantly. Ind. J. Tub. 1991; 38:21-4.

9. Lönnroth K, Williams BG, Stadlin S, Jaramillo E, Dye C. Alcohol use as a risk factor for tuberculosis. BMC Public Health. 2008;8:289.

10. World Health Organization. Stop TB partnership 2007-2008 XDR and MDR Tuberculosis Global response plan.

11. Sei WL, Young AK, Young SY, SangWon U, Sang ML, Chul-Gyu Y et al. The prevalence and evolution of anemia associated with tuberculosis. J Korean Med Sci. 2006;21(6):102832.

12. Weiss G. Pathogenesis and treatment of anaemia of chronic disease. Blood Rev. 2002;16:87-96.

13. Baynes RD, Flax H, Bothwell TH, Bezwoda WR, Atkinson P, Mendelow B. Red blood cell 
Kondo, Wongkar, Ongkowijaya: Gambaran kadar asam urat ...

distribution width in the anemia

Pathol. 1986;85:226-9.

secondary to tuberculosis. Am J Clin 